\title{
HUBUNGAN PENGETAHUAN DAN SIKAP DENGAN PERILAKU SEKSUAL PADA SISWA SMK
}

\author{
CORRELATION OF KNOWLEDGE AND ATTITUDE WITH PREMARITAL SEXUAL BEHAVIOR \\ TOWARD THE STUDENT IN SMK
}

\author{
$\underline{\text { Desi Kumalasari }}{ }^{1}$ \\ Program Studi Kebidanan,STIKes AISYAH Pringsewu, Lampung, 35372, Indonesia \\ d_easi_21@yahoo.co.id
}

\begin{abstract}
ABSTRAK
Perilaku seksual yang tidak sehat di kalangan remaja khususnya remaja yang belum menikah cenderung meningkat. Hal ini terbukti dari beberapa hasil penelitian bahwa yang menunjukkan usia remaja ketika pertama kali mengadakan hubungan seksual aktif bervariasi antara usia 14-23 tahun dan usia terbanyak adalah antara 17-18 tahun. Penelitian ini bertujuan untuk mengetahui Hubungan pengetahuan dan sikap dengan perilaku seksual pranikah pada remaja di SMK Patria Gadingrejo Kabupaten Pringsewu Tahun 2014.Penelitian ini merupakam penelitian analitik dengan menggunakan pendekatan crossectional. Populasi dalam penelitian ini adalah seluruh siswa SMK PATRIA Gadingrejo Kabupaten Pringsewu berjumlah 413 siswa. Sampel dalam penelitian terdiri dari 134 siswa dengan teknik probability sampling. Instrument penelitian dengan menggunakan kuesioner. Analisa data secara univariat dan bivariat dengan menggunakan uji chi square.Hasil analisis univariat menunjukkan bahwa perilaku seksual pranikah pada remaja di SMK PATRIA Gadingrejo Kabupaten Pringsewu yang melakukan perilaku seksual pranikah sebanyak 57,5\%, berpengetahuan baik 62,7\% dan sikap positif 64,9\%. Hasil analisis bivariat: Ada hubungan Pengetahuan $(p=0.000)$ dan sikap $(p=0.000)$. Kesimpulan dari penelitian ini adalah ada hubungan pengetahuan dan sikap dengan perilaku seksual pada remaja di SMK PATRIA Gadingrejo tahun 2014. Guna upaya perbaikan sikap siswa terhadap perilaku seksual pranikah dengan meningkatkan pengetahuan mereka tentang kesehatan reproduksi melalui pengembangan kurikulum pada tingkat jenjang pendidikan serta memberikan pelayanan kesehatan reproduksi bagi remaja.
\end{abstract}

Kata kunci : Pengetahuan, Perilaku seksual pranikah, Sikap.

\begin{abstract}
Unhealthy sexual behavior in teenagers,especially unmarried teenagers tend to increase. It is proved from some research report that teenagers who do sexual intercourse for the firt time in the range of 14-23 years old and the most of the doers are in the range of 17-18 years old. The aim of this research is to know relation of knowledge and attitude with unmarried sexual behavior toward the teenager in SMK Patria Gadingrejo Pringsewu 2014.This research is analistic research which use conventional approach. The participants of this research is the 413 students of SMK PATRIA Gadingrejo Pringsewu. The sample of this research is 134 students with probability technic sampling. The instrument are questionarem analysis the data uses chi-square. The result of analysis shows that unmarried sexual behavior of teenagers in SMK PATRIA Gadingrejo Pringsewu who did the sexual intercourse 57.5\%, knowing well $52.7 \%$, and positive attitude $64.9 \%$.The results of bivariate analysis : There is correlation of Knowledge $(p=0.000)$ and attitude $(p=0.000)$. The conclusion of this research is there is correlation of the knowledge and attitude the unmarried sexual behavior toward the teenagers in SMK PATRIA Gadingrejo Pringsewu 2014. To improve the students attitude toward the unmarried sexual behavior with the incresing their knowledge the reproduction of health by developing the curriculum in the educational level and giving the training to the students.
\end{abstract}

Keywords: Attitude, Knowledge, Unmarried sexual behavior toward 


\section{PENDAHULUAN}

Remaja merupakan potensi yang besar bagi kemajuan bangsa. Namun, jika tidak dibina dengan baik atau dibiarkan saja berkembang ke arah yang negatif, maka akan menjadi beban bagi negara. Sementara kondisi saat ini, menurut hasil survey indicator RPJMN tahun 2012, banyak remaja yang sudah berpacaran dan berperilaku pacaran belebihan. Akibatnya, menyebabkan kehamilan yang tidak dikehendaki dan akhirnya melakukan tindakan aborsi yang tidak aman karena pasangan remaja tersebut belum siap membangun keluarga. Permasalahan remaja itu berkaitan dengan risiko kesehatan reproduksi karena adanya perubahan di sekitar lingkungan hidup remaja. Sementara Badan Dunia bidang Populasi dan Kependudukan (UNFPA) menyatakan bahwa masalah kehamilan pada remaja harus segera diatasi karena dapat menghambat pembangunan suatu bangsa. Salah satu faktor yang dapat menghambat upaya peningkatan kualitas remaja adalah masalah yang berkaitan dengan kesehatan reproduksi remaja. Dari berbagai laporan dinyatakan banyak remaja sudah terjebak dalam perilaku reproduksi tidak sehat, diantaranya perilaku seksual pranikah.

Survei pada 24 negara di Amerika Utara dan Eropa menunjukkan bahwa perilaku seks remaja sudah dimulai sejak usia 15 tahun. Survei dilakukan kepada 33.943 di 24 negara yang dikerjakan oleh sebuah LSM Perancis tersebut, menunjukkan $13,2 \%$ remaja berperilaku seks aktif semenjak usia 15 tahun dan tidak menggunakan alat kontrasepsi. Sementara 82\% lainnya, menggunakan alat kontrasepsi [1]

Di Indonesia, jumlah remaja yang berusia 10-24 tahun mencapai 65 juta orang atau 30 persen dari total penduduk. Sekitar 15-20 persen dari remaja usia sekolah di Indonesia sudah melakukan hubungan seksual di luar nikah. Setiap tahunnya 15 juta remaja perempuan usia 15-19 tahun melahirkan. Hingga Juni 2006 telah tercatat 6332 kasus AIDS dan 4527 kasus HIV positif di Indonesia, dengan 78,8 persen dari kasus-kasus baru yang dilaporkan berasal dari usia 1529 tahun. Diperkirakan bahwa terdapat sekitar 270.000 pekerja seks perempuan yang ada di Indonesia, dimana lebih dari 60 persen adalah berusia 24 tahun atau kurang, dan 30 persen berusia 15 tahun atau kurang. Setiap tahun ada sekitar 2,3 juta kasus aborsi di Indonesia, dimana 20 persen diantaranya adalah aborsi yang dilakukan oleh remaja [2]

Dari sudut pandang kesehatan, perilaku seksual pra nikah remaja, khususnya berciuman berat dan berhubungan kelamin, menimbulkan beberapa risiko, seperti penyebaran penyakit kelamin termasuk HIV/AIDS dan kehamilan yang tidak dikehendaki. Masalah yang di sebut terakhir ini dapat menimbulkan masalah-masalah baru lainnya yaitu aborsi dengan segala risikonya, tingginya angka morbiditas dan mortalitas persalinan, kelahiran bayi prematur dan berat bayi lahir yang kurang.

Penyebab perilaku seks bebas sangat beragam. Pemicunya bisa karena pengaruh lingkungan, sosial budaya, penghayatan keagamaan, penerapan nilai-nilai, faktor psikologis hingga faktor ekonomi. Berdasarkan dari jurnal penelitian dan referensi terkait, mengemukakan beberapa factor yang mempengaruhi perilaku seks bebas baik itu eksternal maupun internal, yaitu latar belakang keluarga, kelompok reverensi atau teman sebaya, perubahan biologis, pengalaman berhubungan seksual, media massa, kurangnya pengetahuan tentang kesehatan reproduksi yang dimiliki remaja, tingkat perkembangan moral kognitif, usia, kekerasan yang terjadi, meningkatnya pergaulan bebas, narkotika, alcohol, psikotropika dan zat adiktif (NAPZA),kemiskinan, status tempat tinggal, religiusitas, dan kepribadian atau identitas diri.

Pengetahuan remaja tentang seks masih sangat kurang. Faktor ini ditambah dengan informasi keliru yang diperoleh dari sumber yang salah, seperti mitos seputar seks, VCD porno, situs porno di internet dan lainnya yang akan membuat pemahaman dan persepsi anak tentang seks menjadi salah. Pengetahuan remaja yang kurang mengetahui tentang perilaku seks pra nikah, maka sangatlah mungkin jika membuat mereka salah dalam bersikap dan kemudian mempunyai perilaku terhadap seksualitas. Selain faktor tersebut yang mempengaruhi dapat pula disebabkan remaja mempunyai persepsi bahwa hubungan seks merupakan cara mengungkapkan cinta, sehingga demi cinta, seseorang merelakan hubungan seksual dengan pacar sebelum nikah.[3]

Dari hasil pre survey yang dilakukan terhadap 11 orang informan mengenai persepsi remaja di kelurahan Wonodadi khususnya di SMK PATRIA Gadingrejo diketahui bahwa ada beberapa kesamaan jawaban dari pihak informan atas pertanyaan-pertanyaan mengenai fenomena seks pranikah yang ada di lingkungan sekolah. Meskipun tanggapan informan yang satu dengan informan lainnya berbeda dalam menanggapinya, tetapi intinya mereka sama. Mereka mempersepsikan, di sekolah mereka terdapat fenomena seks pranikah serta mereka mengetahui fenomena seks pranikah yang ada pada kalangan pelajar di lingkungan sekolah mereka, karena mereka sendiri mengetahui fenomena seks pranikah tersebut banyak dari temanteman mereka yang menceritakan bahwa ia pernah berhubungan intim dengan pasangannya dan tiap tahunnya ada saja murid yang harus putus sekolah karena fenomena seks pranikah. Perilaku seks pranikah di SMK Patria Gadingrejo sudah parah dan sangat 
memperihatinkan karena tiap tahunnya ada para pelajar yang putus sekolah karena hamil di luar nikah.

Berdasarkan fenomena tersebut, segala peraturan dan tindakan hukum telah dilakukan. Akan tetapi masih saja sulit untuk diatasi dan belum ditemukan solusi yang terbaik. Tindakan asusila dan pergaulan bebas (free sex) di beberapa kelompok pelajar disebabkan oleh berbagai faktor. Salah satu faktor penyebab utamanya yaitu minimnya pengetahuan seks yang benar dan terpadu melalui pendidikan formal (sekolah) maupun informal (orang tua).

Mengingat besarnya dampak perilaku seks pranikah, namun di suatu sisi masih rendahnya perilaku pencegahan yang dilakukan oleh remaja maupun lingkungan terhadap hal ini, maka perlu kiranya di gali kembali pengetahuan dan sikap tentang perilaku seks pranikah di masyarakat terutama pada remajanya sendiri. Hal ini perlu dilakukan untuk memberikan solusi atau jalan keluar yang efektif dan efisien supaya perilaku ini tidak merebak di masyarakat.

Berdasarkan hal tersebut diatas maka penulis berkeinginan untuk melakukan penelitian tentang Hubungan Pengetahuan dan sikap dengan perilaku seksual pranikah pada remaja di SMK PATRIA Gadingrejo Kabupaten Pringsewu tahun 2014.

\section{METODE PENELITIAN}

Jenis penelitian ini adalah kuantitatif, menggunakan rancangan penelitian jenis survey dan bersifat analitik, dengan pendekatan waktu pengumpulan data secara bersamaan (cross section) menggunakan alat ukur kuesioner. Objek dalam penelitian ini sebagai variabel independent yaitu pengetahuan dan sikap, sedangkan sebagai variabel dependent adalah perilaku seksual pranikah, subjek penelitian ini adalah remaja SMK, lokasi penelitian dilakukan di SMK PATRIA Gadingrejo Kabupaten Pringsewu pada bulan Maret 2014.

\section{HASIL DAN PEMBAHASAN}

Tabel 1. Distribusi FrekuensiPerilaku Seksual Pranikah PadaRemaja di SMK PATRIAGadingrejo Kabupaten PringsewuTahun2014

\begin{tabular}{ccc}
\hline $\begin{array}{c}\text { Perilaku seksual } \\
\text { pranikah }\end{array}$ & Frekuensi & Persen (\%) \\
\hline Melakukan & 57 & 42,5 \\
Tidak melakukan & 77 & 57,5 \\
Jumlah & $\mathbf{1 3 4}$ & $\mathbf{1 0 0 , 0}$ \\
\hline
\end{tabular}

Pada tabel1. diatas menunjukkan bahwa dari 134 siswa, yang melakukan perilaku seksual pranikah sebanyak 57 siswa atau $42,5 \%$ lebih sedikit dibanding dengan siswa yang tidak melakukan perilaku seksual pranikah yaitu 77 siswa atau $57,5 \%$.

Tabel 2. Distribusi Frekuensi Pengetahuan tentang Perilaku Seksual Pranikah pada Remaja di SMK PATRIA Gadingrejo Kabupaten Pringsewu Tahun 2014

\begin{tabular}{ccc}
\hline Pengetahuan & Frekuensi & Persen (\%) \\
\hline Kurang baik & 50 & 37,3 \\
Baik & 84 & 62,7 \\
\hline Jumlah & $\mathbf{1 3 4}$ & $\mathbf{1 0 0 , 0}$ \\
\hline
\end{tabular}

Pada tabel 2. diatas menunjukkan bahwa paling banyak responden yang berpengetahuan baik yaitu 84 siswa atau $62,7 \%$ sedangkan 50 siswa atau $37,3 \%$ siswa memiliki pengetahuan kurang baik.

Tabel 3. Distribusi Frekuensi Sikap Terhadap Perilaku Seksual Pranikah pada Remaja di SMK PATRIA Gadingrejo Kabupaten Pringsewu Tahun 2014

\begin{tabular}{ccc}
\hline Sikap & Frekuensi & Persen(\%) \\
\hline Negatif & 47 & 35,1 \\
Positif & 87 & 64,9 \\
Jumlah & $\mathbf{1 3 4}$ & $\mathbf{1 0 0 , 0}$ \\
\hline
\end{tabular}

Pada tabel3. diatas menunjukkan bahwa paling banyak responden yang mempunyai sikap positif terhadap perilaku seksual sebanyak 87 siswa atau 64,9\%, sedangkan 47 siswa atau 35,1\% siswa memiliki sikap negatif terhadap perilaku seksual pranikah. 
Tabel 4 Hubungan Pengetahuan terhadap perilaku seksual pranikah pada remaja di SMK PATRIA Gadingrejo Kabupaten Pringsewu Tahun 2014

\begin{tabular}{|c|c|c|c|c|c|c|c|}
\hline \multirow[t]{3}{*}{$\begin{array}{l}\text { Penge- } \\
\text { tahuan }\end{array}$} & \multicolumn{4}{|c|}{$\begin{array}{c}\text { Perilaku Seksual } \\
\text { Pranikah }\end{array}$} & \multirow{2}{*}{\multicolumn{2}{|c|}{ Total }} & \multirow[t]{3}{*}{$\begin{array}{c}\text { p- } \\
\text { value }\end{array}$} \\
\hline & \multicolumn{2}{|c|}{$\begin{array}{l}\text { Melaku- } \\
\text { kan }\end{array}$} & \multicolumn{2}{|c|}{$\begin{array}{c}\text { Tidak } \\
\text { melaku- } \\
\text { kan }\end{array}$} & & & \\
\hline & $\mathbf{N}$ & $\%$ & $\mathbf{N}$ & $\%$ & $\mathbf{n}$ & $\%$ & \\
\hline $\begin{array}{l}\text { Kurang } \\
\text { Baik }\end{array}$ & 33 & 66,0 & 17 & 34,0 & 50 & $\begin{array}{l}10 \\
0\end{array}$ & 0,000 \\
\hline Baik & 24 & 28,6 & 60 & 71,4 & 84 & $\begin{array}{l}10 \\
0\end{array}$ & \\
\hline Jumlah & 57 & 42,5 & 77 & 57,5 & $\begin{array}{l}13 \\
4\end{array}$ & $\begin{array}{l}10 \\
0\end{array}$ & \\
\hline
\end{tabular}

Pada tabel 4. diatas menunjukkan bahwa ada sebanyak $24(42,1 \%)$ siswa yang berpengetahuan baik melakukan perilaku seksual pranikah, sedangkan diantara siswa yang berpengetahuan kurang baik, ada $33(57,9 \%)$ yang melakukan perilaku seksual pranikah. Dari hasil uji statistik diperoleh nilai p-value 0.000 maka dapat disimpulkan adanya Hubungan Pengetahuan dengan perilaku seksual pranikah pada remaja di SMK PATRIA Gadingrejo Kabupaten Pringsewu.

Tabel 5 Hubungan sikap terhadap perilaku seksual pranikah pada remaja di SMK PATRIA Gadingrejo Kabupaten PringsewuTahun 2014

\begin{tabular}{|c|c|c|c|c|c|c|c|}
\hline \multirow[t]{3}{*}{ Sikap } & \multicolumn{4}{|c|}{$\begin{array}{c}\text { Perilaku Seksual } \\
\text { Pranikah }\end{array}$} & \multirow{2}{*}{\multicolumn{2}{|c|}{ Total }} & \multirow[t]{3}{*}{$\begin{array}{c}\text { p- } \\
\text { value }\end{array}$} \\
\hline & \multicolumn{2}{|c|}{$\begin{array}{l}\text { Melaku- } \\
\text { kan }\end{array}$} & \multicolumn{2}{|c|}{$\begin{array}{c}\text { Tidak } \\
\text { Melaku- } \\
\text { kan }\end{array}$} & & & \\
\hline & $\mathbf{n}$ & $\%$ & $\mathbf{N}$ & $\%$ & $\mathbf{N}$ & $\%$ & \\
\hline Negatif & 43 & 91,5 & 4 & 8,5 & 47 & $\begin{array}{l}10 \\
0\end{array}$ & 0,000 \\
\hline Positif & 14 & 16,1 & 73 & 83,9 & 87 & $\begin{array}{l}10 \\
0\end{array}$ & \\
\hline Jumlah & 57 & 42,5 & 77 & 57,5 & $\begin{array}{l}13 \\
4\end{array}$ & $\begin{array}{l}10 \\
0\end{array}$ & \\
\hline
\end{tabular}

Pada tabel 5 diatas menunjukkan bahwa ada sebanyak $43(75,4 \%)$ siswa yang mempunyai sikap negatif melakukan perilaku seksual pranikah, sedangkan diantara siswa yang mempunyai sikap positif, ada 14 $(24,6 \%)$ yang melakukan perilaku seksual pranikah. Dari hasil uji statistik diperoleh nilai p-value 0.000 maka dapat disimpulkan adanya hubungan sikap terhadap perilaku seksual pranikah pada remaja di SMK PATRIA Gadingrejo Kabupaten Pringsewu.

\section{Hubungan Pengetahuan terhadap Perilaku Seksual Pranikah pada Remaja}

Hasil analisis Hubungan Pengetahuan dengan perilaku seksual pranikah pada remaja di SMK PATRIA Gadingrejo Kabupaten Pringsewu yang dapat dilihat pada tabel Pada tabel 4. diatas menunjukkan bahwa ada sebanyak $24(42,1 \%)$ siswa yang berpengetahuan baik melakukan perilaku seksual pranikah, sedangkan diantara siswa yang berpengetahuan kurang baik, ada $33(57,9 \%)$ yang melakukan perilaku seksual pranikah. Dari hasil uji statistik diperoleh nilai p-value 0.000 maka dapat disimpulkan adanya Hubungan Pengetahuan dengan perilaku seksual pranikah pada remaja di SMK PATRIA Gadingrejo Kabupaten Pringsewu.

Menurut Amrillah $(2006)^{[4]}$, semakin tinggi pengetahuan kesehatan reproduksi yang dimiliki remaja maka semakin rendah perilaku seksual pranikahnya, sebaliknya semakin rendah pengetahuan kesehatan reproduksi yang dimiliki remaja maka semakin tinggi perilaku seksual pranikahnya.

Hasil ini di dukung oleh survey yang dilakukan oleh WHO di beberapa negara yang memperlihatkan, adanya informasi yang baik dan benar, dapat menurunkan permasalahan reproduksi pada remaja. Dengan demikian dapat dikatakan bahwa semakin tinggi tingkat pengetahuan remaja maka akan semakin baik perilakunya, karena pengetahuan atau kognitif merupakan domain yang sangat penting untuk terbentuknya tindakan seseorang (overt behavior). Sebagaimana dikatakan oleh Notoatmojo (2003)[5] bahwa perilaku yang didasari oleh pengetahuan akan lebih langgeng daripada perilaku yang tidak didasari oleh pengetahuan.

Survei lain yang dilakukan oleh USeCC (Unnes Sex Care Community) pada mahasiswa UNNES tahun 2008 dengan 160 responden dihasilkan mahasiswa UNNES yang pernah melakukan kissing 43\%, necking $17 \%$, petting $15 \%$, intercourse $5 \%$ dan $20 \%$ responden melakukan aktifitas lain selain kissing, necking, petting dan intercourse. Hasil penelitian deskriptif yang dilakukan oleh jurusan Psikologi UNNES (Universitas Negeri Semarang) pada pertengahan tahun 2009 mengungkapkan bahwa $3,2 \%$ mahasiswa sudah melakukan hubungan seks bebas. Penelitian ini dibedakan antara mahasiswa (533 orang) dan mahasiswi (565 orang). USeCC (Unnes Sex Care 
Community) juga melakukan survei pada akhir tahun 2012 mengenai perilaku seksual mahasiswa. Dari 438 mahasiswa, 29\% mahasiswa melakukan perilaku seksual yang berisiko tinggi dan $71 \%$ mahasiswa melakukan perilaku seksual yang berisiko rendah.[6,7]

Fakta-fakta di atas disebabkan oleh banyak faktor, antara lain masih rendahnya pengetahuan yang dimiliki remaja mengenai seksualitas. Selain itu, meskipun banyak remaja mengetahui tentang seks akan tetapi faktor budaya yang melarang membicarakan mengenai seksualitas di depan umum karena dianggap tabu, akhirnya akan dapat menyebabkan pengetahuan remaja tentang seks tidak lengkap di mana para remaja hanya mengetahui cara dalam melakukan hubungan seks tetapi tidak mengetahui dampak yang akan muncul akibat perilaku seks tersebut.

\section{Hubungan Sikap Dengan Perilaku Seksual pada Remaja}

Hasil analisis Hubungan sikap dengan perilaku seksual pranikah pada remaja di SMK PATRIA Gadingrejo Kabupaten Pringsewu yang dapat dilihat pada tabel 5 diatas menunjukkan bahwa ada sebanyak $43(75,4 \%)$ siswa yang mempunyai sikap negatif melakukan perilaku seksual pranikah, sedangkan diantara siswa yang mempunyai sikap positif, ada $14(24,6 \%)$ yang melakukan perilaku seksual pranikah. Dari hasil uji statistik diperoleh nilai p-value 0.000 maka dapat disimpulkan adanya hubungan sikap terhadap perilaku seksual pranikah pada remaja di SMK PATRIA Gadingrejo Kabupaten Pringsewu.

Menurut Sarwono (2007)[8], semakin tinggi sikap positif (permisif) terhadap perilaku seksual pada remaja mengakibatkan semakin besar kecenderungan remaja untuk melakukan hubungan fisik yang lebih jauh dengan lawan jenis. Penelitian Dariyo dan Setiawati (dalam Amiruddin, 2007)[9] juga memperoleh hasil bahwa memang terdapat hubungan antara sikap terhadap perilaku seksual dengan intensi untuk melakukan hubungan seksual. Ini berarti semakin positif sikap remaja terhadap perilaku seksual maka semakin besar intensinya untuk melakukan perilaku seksual, sedangkan remaja yang memiliki sikap yang negatif terhadap perilaku seksual akan semakin kecil intensinya untuk melakukan perilaku seksual.

Kesesuaian hasil penelitian-penelitian ini mengindikasikan bahwa sikap merupakan predisposisi (penentu) yang memunculkan adanya perilaku yang sesuai dengan sikapnya. Sikap tumbuh diawali dari pengetahuan yang dipersepsikan sebagai suatu hal yang baik (positif) maupun tidak baik (negatif), kemudian diinternalisasikan ke dalam dirinya (Dalimunthe, dkk, 2012[10]). Ini juga sesuai dengan teori L. Green yang menyatakan bahwa faktor predisposisi dalam hal ini sikap berhubungan dengan perilaku seseorang.

\section{KESIMPULAN}

Hasil analisis univariat menunjukkan bahwa perilaku seksual pranikah pada remaja di SMK PATRIA Gadingrejo Kabupaten Pringsewu yang tidak melakukan perilaku seksual pranikah sebanyak 57,5\% lebih banyak dibanding dengan siswa yang melakukan perilaku seksual pranikah, responden yang berpengetahuan baik $62,7 \%$, dan responden yang mempunyai sikap positif terhadap perilaku seksual sebanyak $64,9 \%$.

Adanya Hubungan Pengetahuan Dengan perilaku seksual pranikah pada remaja di SMK PATRIA Gadingrejo Kabupaten Pringsewu diperoleh nilai pvalue 0,000.Adanya Hubungan sikap dengan perilaku seksual pranikah pada remaja di SMK PATRIA Gadingrejo Kabupaten Pringsewu diperoleh nilai pvalue 0,000 .

\section{DAFTAR PUSTAKA}

1. Pahaji ,2008. dalam Perilaku seksual. Tri Amalia

2. Okanegara. 2007. dalam "STRATEGI KOPING PADA REMAJA YANG HAMIL PRANIKAH"

3. Setyawan. A, 2004. Seks Gadis? Memahami Seks Membuktikan Cinta. Yogyakarta : Galang

4. Amrillah. 2006. Hubungan antara Pengetahuan Seksualitas dan Kualitas Kominikasi Anak Orang Tua dengan Perilaku Seksual Pranikah[Skripsi Ilmiah]. Surakarta: Fakultas Psikologi Universitas Muhammadiyah Surakarta.

5. Notoatmojo,S., Pendidikan Dan Prilaku Kesehatan. 2003, Jakarta:Rineka Cipta.

6. USeCC, 2008, Gaya Pacaran UNNES Memprihatinkan, Semarang.

7. USeCC, 2012, Hasil Mini Survei Kependudukan dan Kesehatan Reproduksi, Semarang

8. Sarwono, Solita. Sosiologi Kesehatan: Beberapa Konsep Beserta Aplikasinya. Yogyakata: GMU Press. 2007

9. Dariyo dan Setiawati. Hubungan Antara Sikap Terhadap Perilaku Seksual Dengan Konformitas Terhadap Teman Sebaya Pada Remaja Madya.Skripsi UI: Jakarta. 2007

10. Dalimunthe, Candra Rukmana dan Kristina Nadeak. 2012. Tingkat Pengetahuan Pelajar SMA Harapan-1 Medan Tentang Seks Bebas Dengan Risiko HIV/AIDS. EJournal FK USU,1(1) 
